\title{
The Presentation of President Obama's Ideologies in View of the Five Discursive Strategies
}

\author{
Supeno \\ English Department \\ Universitas Wijaya Kusuma (UWKS) \\ Surabaya, Indonesia \\ bana.supeno@gmail.com
}

\author{
Slamet Setiawan \\ Universitas Negeri Surabaya (UNESA) \\ Surabaya, Indonesia \\ slametsetiawan@unesa.ac.id
}

\author{
Oikurema Purwati \\ Universitas Negeri Surabaya (UNESA) \\ Surabaya, Indonesia \\ oikuremapurwati@unesa.ac.id
}

\begin{abstract}
As a US president, Obama was not a particularly ideological person, but remains passionate about certain issues. That is, everybody should get a fair shake and should be treated with dignity or respect regardless of what they look like or who they are. Some even state that he is pretty pragmatic in how Americans get it. There are some what he called impediments to the "progress and change" in getting what he proposed done. Despite the fact that this statement was made domestically, there are some proofs in his three international speeches; in Cairo (2009), Berlin (2013), and Havana (2016), that these are the ways in which his ideologies-representing the US-presented to the world. Discussed descriptively and qualitatively in terms of Five Discursive Strategies as a particular aspect of Critical Discourse Analysis, this paper is intended to elaborate how President Obama presents his (American) ideologies in the three speeches. Based on the analysis of the data selected from the three speeches it is found that in view of the Five Discursive Strategies President Obama's ideologies are mostly presented consistently and somewhat differently.
\end{abstract}

Keywords: ideology, presented, Five Discursive Strategies.

\section{INTRODUCTION}

Numerous researchers analyzed the data selected from one or more speeches delivered by President Obama (hereinafter termed PO) in terms of rhetoric, critical discourse analysis, cognitive-sociolinguistics, stylistics, or semantics. Most of them analyzed the data to find and describe the points that PO intended to convey in his speech or speeches in terms of the theories applied. Applying cognitive theory of sociolinguistics, Zhang Lin [1] managed to investigate the cognitive aspects to build the speaker's mental model based on the current situation faced by the US and its people.

Oti , a graduate student of Gonzaga University, makes a research in terms of metaphors to investigate the metaphorical content of PO's speech in Cairo, Egypt, on June 4, 2009, focusing on the metaphoric elements of rapprochements and global coexistence in PO's Cairo speech. The result shows that PO's metaphoric arguments are (a) the reordering of President Bush's war rhetoric, and (b) the suggestions of peace as an alternative. Oti concludes that PO's speech in Cairo constitutes a glaring, representative anecdote that falls into the rare category of peace rhetoric.

Carried out in terms of Critical Discourse Analysis (CDA), Rahmani [2] of Razi University of Iran analyzes New York Times' approach toward Iran before and after PO. Analyzing the representation of Iran and the matters related to Iran in the NewYork Times in two periods of before and after PO's adjuration on January 21, 2009, Rahmani notes two different things. In the period before PO, the general policy of the US was based on preemption: intensifying the sanction against it and by posing a military threat. In the period during PO, the general policy of US was based on negotiation with Iran to solve the existing problems. In terms of CDA and Systemic Functional Grammar (SFG), Rahmani concludes that the change in the policy of government as the most powerful institute of the society has brought about change in the approach of the newspaper toward Iran.

There are a lot more researches by graduate students made by analyzing selected PO's speeches. Researches made to find how PO presents his ideologies, however, are still difficult to find. Numerous others are in the forms of journal articles, otherwise articles in partial analyses [3];[4];[5];[6]. Thousands or hundreds thousands others are just short essays about PO's speeches [7][8];[9];[10];[11];[12] are just to mention some. Most of the conclusions made, therefore, are only theoretical descriptions of personal views about the speeches.

Analyzing three PO's speeches in Cairo, Berlin, and Havana this paper is intended to discuss how PO present his (American) ideologies in terms of the Five Discursive Strategies (hereinafter termed FDS). FDS is a 'discourse-analytical tools' proposed by Wodak and Meyer [13], consisting of linguistic elements assumed as the linguistic features of the texts of the speeches as the discourses under analysis. In essence, this paper is intended to answer the questions, "How are American ideologies in the three speeches presented in terms of The Five Discursive Strategies?" 


\section{THEORETICAL VIEWS}

\section{A. CDA and Ideology}

The shared perspective relates to the term 'critical'-in terms of Critical Discourse Analysis - could be traced to the influence of the Frankfurt School or Juergen Habermas [13]. Quoting Fairclough's view, Wodak and Meyer state that in human matters, interconnections and chains of cause and effect may be distorted out of vision. Hence, 'critique is essentially making visible the interconnectedness of things'. They further state that Critical Linguistics (CL) and CDA may be defined as fundamentally concerned with analyzing opaque as well as transparent structural relationships of dominance, discrimination, power and control as manifested in language. Thus, CDA aims to investigate critically social inequality as it is expressed, signaled, constituted, legitimized and so on by language use (or in discourse). Also quoting Habermas they state that most critical discourse analysts would thus endorse Habermas' claim that language serves to legitimize relations of organized power in so far as the legitimations of power relations are not articulated. Language is, thus also ideological; it bears the concepts of ideology.

In Language and Power [14] Fairclough sets out the social theories underpinning CDA and a variety of textual examples are analyzed to illustrate the field, its aims, and methods of analysis. Later Fairclough [14], Chouliariki and Fairclough explain and elaborate some advances in CDA, showing not only how the analytical framework for investigating language in relation to power and ideology developed, but also how CDA is useful in disclosing the discursive nature of much contemporary social and cultural change. CDA, therefore, is a method applied as the method of analysis, and it can be understood that CDA is an analytical framework for investigating language in relation to power and ideology in the three PO's speeches [15]; [13]

In discourse's view, language is a form of social practice. As a part of society it is not external to it. It is a social process and it is socially conditioned process, which means it is conditioned by other (non-linguistic) parts of society)[16]. Discourse itselfas a political practice - establishes, sustains, and changes power institutions and the collective entities (classes, blocks, communities, groups) between which power reasons obtain. As an ideological practice discourse constitutes, naturalizes, sustains, and changes significations of the world from diverse positions in power relations [14]

Based on Fairclough's views above, it can be assumed that the three PO's speeches are also political and or ideological discourses [17] That is, as political and ideological discourses, the speeches might have some possible capacity of establishing, sustaining, and even changing the power institutions or power relations as the collective entities which suit the global community. Such capacity is - to use Fairclough's terminvested or reinvested in discursive ways by considering - again to use Fairclough's term-social domains or institutional settings. It is also assumed therefore that the three PO's speeches have undergone a process of change which in terms of CDA may be called 'discursivication': the process of changing from concise into discursive speech that manifests in political discourse.

\section{B. How Ideologies are Presented}

Since the term ideology is not easy to define, writers often define this term by referring to dictionary. Nevertheless, most scholars will agree that ideology plays a central role in one's attitudes, beliefs and behaviors. Humaid [18] states that ideology is shown to be influenced by the shifts in registers, changes in general discourse, and unintentional shifts caused during translation. In another series of studies, inter-textual analysis and CDA are shown to uncover ideologies, while changes in discourses across time uncover changes in ideologies. As 'social formation', ideologies are (a) influenced by the language (registers, discourse, and unintentional shifts of translation) and the inter-textuality, and (b) CDA is capable to uncover such ideologies [19]

In Discourse, Grammar and Ideology: Functional and Cognitive Perspectives, Hart [20] identifies a number of different dimensions of discourse where ideology may lurk. He further states that linguistic representation is the ideological potential. Representation, in his view, concerns the depiction of social actors, situations and events. He also reminds, however, that linguistic expressions do not correspond directly with the realities the language describes. Rather, the grammar of representation, located in the ideational function of language, yields a linguistic product which reflects but a particular take on reality which may thus be ideologically infused.

In this particular paper, the way ideology is represented discursively is viewed in terms of the 'Five Discursive Strategies' (FDS), also called 'discourse-analytical tools' [13] The five strategies or the analytical tools consist of linguistic elements. It is assumed that they are the linguistic features of the texts (of the speeches) or the discourses under analysis.

The concept of FDS is developed by Wodak and Meyer in their two year-research on CDA based on discourse-historical approach[13]. They state that the notion of 'discourse' is the discourse-historical approach that perceives both written and spoken language as a form of social practice. As such, it can be seen as constituting non-discursive and discursive social practices as being constituted by them[13]. They offer the five strategies of (1) referencing, (2) predicating, (3) arguing, (4) perspectivicating or framing, and (5) intensifying or mitigating [13].

There are several discursive elements and strategies which, in discourse-analytical view, deserve to receive special attention. Selecting five of the many different linguistic or rhetorical means by which persons are discriminated against in an ethnicist or racist manner, they orientate themselves to five simple, but not at all randomly selected questions. They are (1) How are persons named and referred to linguistically? (2) What traits, characteristics, qualities and features are attributed to them? (3) By means of what arguments and argumentation schemes do specific persons or social groups try to justify and legitimize the exclusion, discrimination, suppression and exploitation of others? (4) From what perspective or point of view are these labels, attributions and arguments expressed? (5) Are the respective utterances articulated overtly? Are they intensified or are they mitigated? 


\section{The Thee PO's SPeEches: The SOURCE OF THE DATA}

The sources of the data in this paper are the full texts of PO's three different speeches delivered in Cairo,Berlin, and Havana. They are taken from the official website of "The American Speech Banks", where the authenticity of the speeches is certified [21];[22]; and [23]. Similar texts are available in many other resources freely and officially.

The data to be analyzed are in the form of (groups of) fragments and or sentences, where each of them contains PO's ideology. Once an issue-in the forms of a group of fragments and or sentences representing the ideology-is identified, it is analyzed using the aspect of the FDS proposed by Wodak and Meyer [13]. As the results of the selection, some sentences or fragments that are potential as containing hidden ideologies are taken as the data. It is in the groups of fragments and or sentences that the ideologies are - to use Fairclough's term-lurking.

\section{How PO's IDEOLOGIES ARE PRESENTED IN VIEW OF FDS}

\section{(1) On Extremism and War on Terrorism}

While in Cairo PO calls it confrontation with extremism, in Berlin and Havana he calls it the war on terrorism. Here, PO is using the first strategy (S1) of FDS: predicating the persons he fights as 'the extremists' or 'terrorists', with the second objective (O2) of FDS: labeling them negatively, and with the second device (D2) of FDS, stereotyping [13]. This point is supported using arguments in the form of giving the reason that the "extremists' actions are irreconcilable with the rights of human beings, the progress of nations, and with Islam". He also argues and quotes the teaching of the Holy Quran that whoever kills an innocent is as - it is as if he has killed all mankind and whoever saves a person, it is as if he has saved all mankind. In terms of FDS, this can be called the strategy (S2) argumentation, with the objective of $(\mathrm{O} 2)$ justifying negative attributions, using the device of (D2) preferential treatment (fighting).

In Berlin this ideology is presented by giving some arguments in the forms of evidences about "the successes of the war on terrorism in Iraq, in Afghanistan, no more Osama bin Laden, and the evolving efforts against al Qaeda". As the continuation of the war, PO states that "America has to move beyond a mind-set of perpetual war, which means redoubling the efforts to close the prison at Guantanamo". Supported with more evidential steps, PO states that "all of these will help confront real dangers, and they keep people safe in the US and Europe". Here, PO is using two strategies of (S3) argumentation and (S5) intensification, with the objective of $(\mathrm{O} 4)$ positioning the speaker's point of view, using the device of (D5) mitigating the illocutionary force of utterances.

Similar ideology is presented in Havana by stating "the thoughts and the prayers of the Americans are with the people of Belgium. America stands in solidarity with the people of Belgium in condemning the outrageous attacks against innocent people and will do whatever is necessary to support our friend and ally, Belgium, in bringing to justice those who are responsible". He also reminds that "the world must unite and that people in the world must be together in fighting against the scourge of terrorism". PO is sure "people can and will defeat those who have done this". In terms of FDS, PO is using nomination strategy (S1), with the objective to (O1) construct the in-group, using the device (D1) pars-pro-toto added with mitigation (S5), with the objective (O5) modifying the epistemic status of the proposition, by using the device (D3) preferential treatment as well as (D5) intensifying the illocutionary force.

\section{(2) On Nuclear Weapons}

Presented in Cairo, PO points that "nuclear weapons is about preventing a nuclear arms race in the Middle East that could lead this region and the world down a hugely dangerous path". In Berlin the objects of the issue are Russia, North Korea, and Iran, and the USA itself. He states that "all people may no longer live in fear of global annihilation, but so long as nuclear weapons exist, we are not truly safe". Differently, in Havana PO states "this entire world was once threatened by the great horror of nuclear war between USA and Cuba".

Measured in terms of FDS, in Cairo PO is using the strategy of (S1) referential by using the device (D1) membership categorization with the objective (O1) to construct both ingroups and out-groups. In constructing the in-groups, he states "the source of tension is our shared interest in the rights and responsibilities", which means he includes the audient (Egypt) into his group. However, he also constructs the out-group by stating that "this issue has been a source of tension between the US and the Islamic Republic of Iran", which clearly means that it is none of the business of other countries.

Almost similarly, in his Berlin speech PO is also using the strategy of (S1) referential with the objective to $(\mathrm{O} 1)$ construct a sense that Russia, North Korea, and Iran are out of 'his' group. The device is (D1) membership categorization; Russia, North Korea, and Iran as the countries to be part of USA and Germany's suspicion of seeking nuclear weapons. The strategy and the out-group construction are more sensible in "but so long as nuclear weapons exist, we are not truly safe". In Havana PO is using the strategy of (S3) argumentation, with the objective (O3) to justify the positive side of what USA and Cuba have avoided - the horror of nuclear war between USA and Cuba, with the device of (D3) preferential treatment-avoidance or getting away from the nuclear war. It can also be understood that the strategy used in telling this (the success of avoiding nuclear war) is capable of producing positive - to use Wodak and Meyer's term — psychological or linguistic aim [13]

\section{(3) On Democracy}

Presenting this ideology in Cairo, PO states that much of the controversy in promoting democracy is connected to the war in Iraq. He states that "No system of government can or should be imposed by one nation by any other". He reiterates that "any government should reflect the will of the people", and underlines that "These are not just American ideas; they are human rights", and argues "Governments that protect these rights are ultimately more stable, successful, and secure". In view of FDS, he is using the strategy of $(\mathrm{S} 3)$ argumentation with the objective $(\mathrm{O} 3)$ to justify the negative attributions to Iraq. By mentioning Iraq, it is also obvious that - to use Wodak and Meyer's term-he articulates the strategy overtly. $\mathrm{He}$ is also justifying positive attributions to himself (America) and the audient (Egypt). Thus the device is (D3) topoi, where he justifies political exclusion of Iraq as the country who does not protect democracy and the inclusion of USA and Egypt. 
In Berlin speech, he states that we (USA and Germany) "must accept the challenge that the democratic governments face: to listen to the voices who disagree with us; to have an open debate about how we use our powers and how we must constrain them; and to always remember that government exists to serve the power of the individual, and not the other way around". In his view, "these are the three criteria that make who we are, and what make us different from those" (presumably Russia and its group). Thus, he is using (S3) argumentation with the objective (O3) to justify both the positive as well as the negative attributions to democratic countries and nondemocratic countries. It can also be seen that he covertly (O2) constructs the in-group (USA and Germany) as well as the outgroup (Russia and its group). In terms of devices, he is using (D3) topoi by justifying political inclusion of "us" and exclusion of Russia (and its group).

As in Havana the ideology on democracy is presented differently by picking up examples of problems in his own country (USA) and points out that democracy is the solution of them. PO states "there are still enormous problems in the US society, but democracy is the way that USA solves them". He further states that "there are still some tough fights, and the process is not always pretty, and the process is often frustrating". As such, PO is using (S2) predication which means how those examples are named or referred to linguistically, with the objective of (O2) labeling American government as the social actors appreciatively, using the device of evaluative attributions of positive traits (D2) as well as (D5) mitigating the illocutionary force because he states that "democracy is the way that USA solves them".

\section{(4) On Religious Freedom and Justice and Tolerance}

Presenting this ideology in Cairo, PO states religious freedom is "a situation where people in every country should be free to choose and live their faith based upon the persuasion of the mind and the heart and the soul. This tolerance is essential for religion to thrive but is being challenged in many ways". He argues that "among some Muslims, there's a disturbing tendency to measure one's own faith by the rejection of somebody else's faith", reasoning that "people must always examine the ways it is protected, and it is important for Western countries to avoid impeding Muslim citizens from practicing religion as they see fit by dictating what clothes a Muslim woman should wear". In terms of FDS, one can see that PO is using strategy (S4) to frame his view, with the objective $(\mathrm{O} 4)$ to position himself in a point of view, using the device of (D4) reporting, describing, or narrating the situation.

In Berlin he states that "peace with justice begins with the example we set here in USA and Germany, for they know from their own histories that intolerance breeds injustice". In his view, "--- USA and Germany are stronger when all of the people-no matter who they are or what they look like and no matter if they are males or females - are granted opportunity". He also argues and reasons "as long as walls exist in the hearts to separate people from the other, it will hard to bring down those walls of division". When viewed in terms of FDS, he is using the strategy of (S3) argumentation, with the objective (O3) to justify the positive as well as the negative sides of what he points out, and using the device of (D3) preferential treatment to solve the problems of injustice.
(5) On Economic Development and Opportunity, and Trade and Commerce

In Cairo this ideology is presented in controversy between opportunities and disruptions of culture and identities. He states "for many, the face of globalization is contradictory". Giving three evidential contradictory arguments about the things related to globalization, he argues "since human progress cannot be denied, there need not be contradictions between development and tradition". Giving examples and detailed reasons, PO offers the solution that "all these things must be done in partnership because people can only achieve it together". In terms of the FDS it is obvious that he is using (S4) perspectivication, with the objective $(\mathrm{O} 3)$ to justify the positive and the negative sides of the development and human progress, and (O4) positioning his point of view. By giving detailed reasons and solutions, he is using the device of (D4) describing the events and (D5) mitigating the illocutionary force.

In Berlin the ideology on trade and commerce is presented by staying that "although USA and Germany trade and commerce are the engine of their global economy, the values call upon them to care about the future unpredictable lives of people". He further states that "the real prosperity comes from our most precious resource-the people", and this is the reason why US chooses to invest in education, science, and research. PO suggests that "---, create new opportunity in their own societies while pursuing new trade and investment that fuels growth across the Atlantic". In terms of FDS, one can see that PO is using the strategy of (S4) perspectivication, with the objective (O4) to express the speaker's point of view, with the device (D4) to describe the circumstances. He is also using (D1) metaphor when he is stating that people are the most precious resource.

\section{(6) On Ideology on Israel, Palestina, and the Arab World}

In presenting this ideology, PO states that the cultural and historical bonds between America and Jewish people-who were prosecuted for centuries and culminated in holocaust-are unbreakable. Supporting this point he states that (a) he will visit Buchenwald where six million Jews were killed by Third Reich; (b) Denying that fact is baseless; it is ignorant; and it is hateful; (c) threatening Israel with any means is wrong and only preventing the peace that is deserved. PO also states that it is undeniable that (a) the Palestinian people-Muslims and Christians - has suffered in pursuit of a homeland, and (b) more than 60 years they have suffered from dislocation caused by the Jewish's intolerable occupation. Promising that America will not turn their backs on the legitimate Palestinian aspiration for dignity, opportunity, and a state of their own, PO concludes that for peace to come both sides, all of us should live up to our responsibilities.

In view of FDS, he is using the strategy of (S1) nomination, with the objective $(\mathrm{O} 1)$ to construct in-group or out-group, using the device of (D1) membership categorization. At the same time, he is also using strategy of (S4) perspectivication, with the objective (O4) to position his point of view, by (D4) narrating the circumstances. In his conclusions, however, he is using the strategy of (S5) mitigation, with the objective (O5) to modify the proposition, using the device (D5) to mitigate the illocutionary force. 


\section{(7) On Women's Equality of Rights}

In Cairo, PO presents this ideology by stating that "well educated women are more likely prosperous". In view of FDS, $\mathrm{PO}$ is trying to argue what women's equality of rights is, which means he is using the strategy of (S3) argumentation where the objective is (O3) to justify the positive or negative aspects of giving women equality of rights, using the device of (D2) stereotyping or evaluating the attributions. When he convinces that "daughters can contribute just as much as sons and that prosperity will be advanced by allowing men and women to reach their full potential", he is using the strategy of (S4) framing the audient's perspective, with the objective (O4) to express and position the speaker's point of view, using the device of (D5) mitigating the illocutionary force.

(8) On Humanity, Moral Obligation, Poverty, and Diseases

In presenting this ideology PO points that "the threats of today are the struggles for freedom and security of human dignity" and points out that US and Germany should: (a) care more about things than just their own self-comfort, own city, and own country; (b) demand that they embrace the common endeavor of all humanity; (c) recognize that their work is not yet done; (d) understand that they are also citizens of the world, and link their fates and fortunes like never before. PO reasons that "in order to live in peace with justice US and Germany can help the citizens of the world struggle in humanity, moral obligation, poverty, and diseases". He further reasons that "threats to freedom do not come merely from the outside, but can emerge from within, own fears, the disengagement of citizens".

In view of FDS, PO is using the strategy (S4) perpectivication by trying to frame the audient's perspective. As such, his objective is (O4) to express or position his point of view about what US and Germany should do, with the device of (D4) describing or narrating the circumstances. In giving the solution, he is using the strategy of (S5) mitigation of how to live in peace with justice, with the objective (O5) to modify the epistemic status of proposition, using the device of (D5) mitigating the illocutionary force of his statements.

\section{(9) On Climate Change}

In short discussion, this ideology is presented in relation to peace with justice for the future generation. PO points that "Germany and Europe have led on the effort to slow down the climate change for the future children", and supports this view by stating what US has done so far: (a) doubling the renewable energy from clean sources like wind and solar power; (b) doubling fuel efficiency on cars to make the dangerous carbon emissions come down. In view of FDS, he is using the strategies (S1 and S3) nomination and argumentation, with the objectives of (O1 and O3) construction of in-group and justification of positive attributions (of what USA and Germany have done so far). By mentioning the involvement of the two countries, he is using the devices (D1 and D3) membership categorization and topoi used to justify political inclusion.

Meantime, when he states that "--- there must be an effort of all nations in order to alter the affects all nations caused by more severe storms, more famine and floods, new waves of refugees, coastlines that vanish, oceans that rise". PO views that "this is the future global threat that must be averted for the sake of future generations before it is too late". As such, he is using the strategy
(S4) framing the perspective of the audient, with the objective (O4) expressing or positioning the speaker's point of view, using the device (D4) mitigating the illocutionary force of his statements.

\section{(10) On Differences and Disagreements between USA and Cuba}

To present this ideology PO states that "despite the differences, they share common values that their grandchildren will look back at the period of isolation and aberration as just one chapter of a longer story of family and friendship". Here, it is obvious that PO is trying to $(\mathrm{S} 1)$ nominate Cuba, with the objective (O1) to construct in group, using the device (D1) membership categorization. He is also trying to make (S3) argumentation, with the objective (O3) to justify the positive attributions, using (D3) preferential treatment. This is especially when he argues that the two countries cannot and should not ignore the very real differences that they have about many things. Furthermore, he is trying to (S4) frame the audient's perspective, with the objective of $(\mathrm{O} 4)$ expressing or positioning the speaker's point of view, using the device of (D4) reporting and narrating events.

Almost similarly, in presenting about the disagreements between the two countries, PO points that "there is no secret that the US and Cuban governments disagree on many issues". PO can understand that President Castro points the flaws of the American system as in economic inequality; the death penalty; racial discrimination; and wars abroad, and many more. In view of FDS, PO is using strategy (S2) predication, with the objective $(\mathrm{O} 2)$ labeling both the positive and the negative actors (USA and Cuba), using the device of (D2) stereotyping or evaluating their positive and negative attributions. However, when he mentions that despite too much money in American politics, it is still possible for PO to pursue and achieve the highest office in the land, he is using the strategy (S3) argumentation with, the objective (O3) justifying the positive attributions about the US government, using the device of (D3) topoi to justify the political American inclusion.

\section{(11) On USA will not Change Cuba}

To present such ideology, PO points that in the past the two countries were in political and personal disputes. In FDS, this means that he is using the strategy $(\mathrm{S} 1)$ referential or nominating that in the past USA and Cuba as two different groups, with the objective (O1) to construct in or out groups about the two countries, using the device of (D1) membership categorization of the two countries. To support the point he states that "the US has neither the capacity nor the intention to impose change on Cuba" reasoning that "what changes come will depend upon the Cuban people and that the US will not impose its political or economic system on Cuba" because "every country, every people, must chart its own course and shape its own model". Here, he is using strategy of (S4) framing the audient's perspective, with the objective (O4) to express or position the speaker's point of view, using the device of (D4) where he is trying to describe or narrate the events to support his point.

\section{(12) On Equality under the Law}

In this ideology, PO believes that (a) every child deserves the dignity that comes with education, health care and food on the table and a roof over their heads, (b) citizens should have the 
freedom to speak their mind without fear; organize and criticize their government; protest peacefully, and the rule of law should not include arbitrary detentions of people who exercise those rights, and (c) every person should have the freedom to practice their faith peacefully and publicly. He also believes that (d) voters should be able to choose their governments in free and democratic elections. In view of the FDS, PO is using both (S3) argumentation by telling what he believes, and (S4) perspectivication by framing the audient's perspective. As such, the objectives are to (O3) justify the positive attributions and (O4) to express or position his point of view. It is also obvious that he is using (D3) preferential treatment and (D4) describing or narrating what the preferred things to make equality under the law.

\section{(13) On Co-operations between USA and Cuba}

This ideology is presented by quoting examples of some forms co-operations between the two countries that are believed to bring some hopes. He points that "after being on different of so many conflicts, USA and Cuba are now sitting together at the negotiating table to help the Columbian people resolve a civil war". When viewed in terms of FDS, one can see that PO is using the strategy (S2) predication, with the objective $(\mathrm{O} 2)$ labeling both USA and Cuba as more positive actors, using the device of (D2) stereotyping or evaluating some positive attributions to the two countries.

\section{(14) On New Era (Reconciliation)}

To present this ideology, PO states that "since USA and Cuba are in the new era, the two countries do not need to define themselves as against each other". PO is "hopeful for the future of the reconciliation that is taking place among Cuban people". He also details about Cuban people who live in the US or in exiles as the evidential arguments, telling that they feel being exiles and it is not just about politics but also about family, the lost home, and the hope for better future and reconciliation. In view of FDS, both the main point as well as the supporting points are the strategy of (S4) framing the audient's perspective about the old and new era, with the objective of (O4) expressing the speaker's point of view, using the device of (D4) describing or narrating the events (of the old and the new era).

\section{CONCLUSION}

Based on the discussion above, it can be seen that in view of the FDS, most ideologies in the three speeches are presented similarly; in similar strategies, aiming similar objectives, and using similar devices. Some others, however, are presented in different strategies, aiming at different objectives, and using different devices. In terms of FDS as one aspect of CDA, this is - seemingly-because the contexts (times, places, and the cultures) of the three speeches are different. It is also found that out of 14 (fourteen) ideologies, referential or nomination is used 7 (seven) times in presenting the ideologies, while predication is used only 3 (three) times. Argumentation is used 10 (ten) times, the second most frequent usage. Perspectivication is used 12 (twelve) times which is the first most frequent usage, while intensification or mitigation is used 3 (three) times, similar to that of predication.

\section{REFERENCES}

[1] Lin and Zhang, "The Critical Discourse Analysis of Barack Obama's Inaugural Address: A Social-Cognitive perspective,” 2010.

[2] Rahmani and Diyako, "Change In Practice: A Critical Discourse Analysis of New York Times' Approach Toward Iran, Before And After Obama," Razi University, 2010.

[3] Gatta and T. Michael, Uniting A Nation: A Close Textual Analysis of Barack Obama's Inaugural Address. 2010.

[4] Nitsch, Cordula, and C. Eilders, "No TitlFictional Politics on TV: Comparing the Representations of Political Reality in the U.S. Series The West Wing and the German Series Kanzleramte," Glob. Media J. (German Ed., vol. 5, no. 1, 2015.

[5] J. Savoy, Lexical Analysis of Obama's and McCain's Speeches. Switzerland, 2009.

[6] Stobbs and J. Gary, "Critical Discourse Analysis of Barack Obama's 1st Inaugural Speech," 2012.

[7] All Answers Ltd, How Important Is Race Factor In Us Politics. 2015.

[8] Dutton and Sarah et al, "President Obama: Ukraine and Foreign Policy," (C) 2014 CBS Interactive Inc. CBS NEWS March 25, 2014, 6:30 PM, 2014.

[9] Editorial Board, "President Obama's Foreign Policy is Based on Fantasy: The Post's View," March 2, 2014, 2014.

[10] Kagan and Robert, "President Obama's Foreign Policy Paradox: Opinions," March 26, 2014, 2014.

[11] Nordquist and Richard, "What Is Barack Obama's Secret for Giving a Great Speech?: How to Inspire an Audience With the Magic Number Three," 2016.

[12] The Brookings Institution, “Obama's Egypt Speech: What $\mathrm{He}$ Should Say to the Muslim World," 2009.

[13] Wodak, Ruth, and M. Meyer, "Methods of Critical Discourse Analysis," SAGE Publications Ltd, 2001.

[14] N. Fairclough, Discourse and Social Change. Blackwell Publishing Limited, 1992.

[15] Waugh and L. R, "Critical Discourse Analysis: Definition, Approaches, Relation to Pragmatics, Critique, and Trends," University of Nebraska, 2015.

[16] N. Fairclough, Language and Power. UK: Longman Group UK Limited., 1989.

[17] Hart, Christopher, and D. Lukes, Cognitive Linguistics in Critical Discourse Analysis: Application and Theory. Cambridge Scholars Publishing, 2007.

[18] Humaid and B. Abdalla., "Language and Ideology: A Discourse and Translation Perspective," the American University of Sharjah, 2014.

[19] V. Dijk and T. A, "Ideology: A Multidisciplinary Approach," SAGE Publications, 1998.

[20] Hart, Christopher, and D. Lukes, Discourse, Grammar and Ideology: Functional and Cognitive Perspectives. Bloomsbury Publishing Plc, 2014.

[21] Eidenmuller and M. E, "(Barrack Obama) A New Beginning: Speech at Cairo University,” 2009.

[22] Eidenmuller and M. E, "(Barack Obama:) Brandenburg Gate Address," 2013.

[23] Eidenmuller and M. E, "(Barack Obama:)Address to the People of Cuba," 2016. 